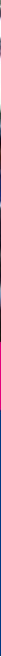

\title{
Favouring local development in the Amazon: Lessons from community forest management initiatives
}

\author{
Gabriel Medina, Benno Pokorny and Bruce Campbell
}

\section{Introduction}

The advancing development frontier across the Amazon Basin is opening up new opportunities for traditional and indigenous communities with rights over large forest areas. These opportunities to profit from commercialising forest products, especially timber, promise to improve livelihoods in the rural Amazon - but only if local communities have ownership over the ways in which their resources are exploited.

Typically, community leaders or individual families negotiate informal contracts with logging companies to harvest commercially valuable trees in exchange for cash. However, the companies often dictate the terms and pay little, if at all (Medina, 2004), while poor logging practices cause immense damage to the remaining forest stands (Sabogal et al., 2008). As a consequence, particularly after repeated harvesting, forests become so degraded that communities often lose non-timber forest resources that are essential to their livelihoods (Shanley et al., 2002).

Development agencies have responded by supporting local communities to harvest timber themselves, based on prescribed management plans devised by outside experts and authorised by central government agencies. NGOs and government agencies, supported by international donors, have established so-called pilot community forestry projects in the Amazon to demonstrate the viability of this approach (Pokorny and Johnson 2008).

However, research for the EU-financed ForLive ${ }^{1}$ project reveals that community forestry initiatives in the Bolivian, Peruvian and Brazilian Amazon are not fulfilling their high expectations. The initiatives are often not compatible with local realities and development agencies require local communities to manage their forests according to priorities determined by the agency. More equitable partnerships are necessary if communities really are to be supported in more effectively using their forests.

\footnotetext{
1 Forest management by small farmers in the Amazon - An opportunity to enhance forest ecosystem stability and rural livelihoods (ForLive) (http://www.waldbau.unifreiburg.de/forlive/Project.html)
} 
As it stands, community forestry as promoted in the Amazon is less attractive for local communities than the meagre benefits gained from logging companies. Development agencies as well as logging companies are hindering communities' efforts to develop, organize and implement their own ideas about how best to use their resources.

This policy brief aims to establish the importance of genuinely equitable partnerships in local forest management schemes. It analyses the circumstances favouring communities in developing management regimes based on their own interests and capacities, and outlines how development agencies can promote autonomous development.

\section{Case studies}

This policy brief is informed by research in four areas in Bolivia, Brazil and Peru, all typical frontier regions characterized by rapidly increasing timber markets (Figure 1). In each study area two communities were selected as case studies: one negotiating its timber rights with logging companies and one receiving support from a development agency to adopt community forest management. These eight communities were studied between 2005 and 2008.

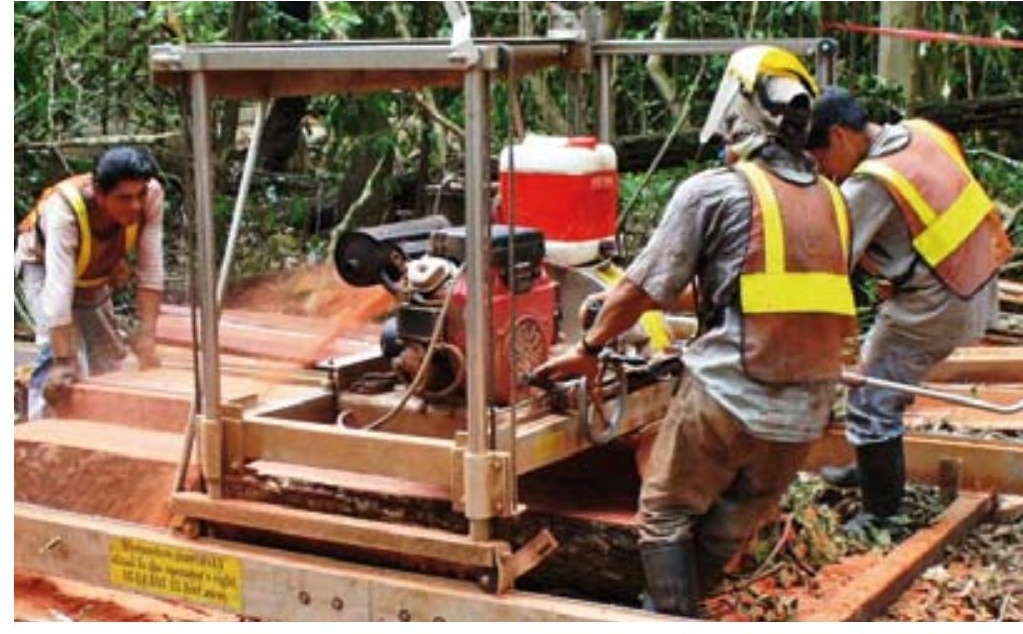

Indigenous people trained by an NGO saw timber felled in certified forest operations. Such pilot initiatives support communities in managing their forests, but externally-defined management practices are usually abandoned once the support ends. (Masisea, Peru)

\section{Limited Attractiveness of Community Forestry}

In all four study areas, nearly all communities (96 per cent) informally negotiated timber rights with loggers. In contrast, less than two per cent participated in community forestry initiatives (Figure 2), and most abandoned the management practices once external support ceased. In some cases, these communities resumed negotiations with loggers.

Figure 1. Study areas in the Brazilian, Bolivian and Peruvian Amazon

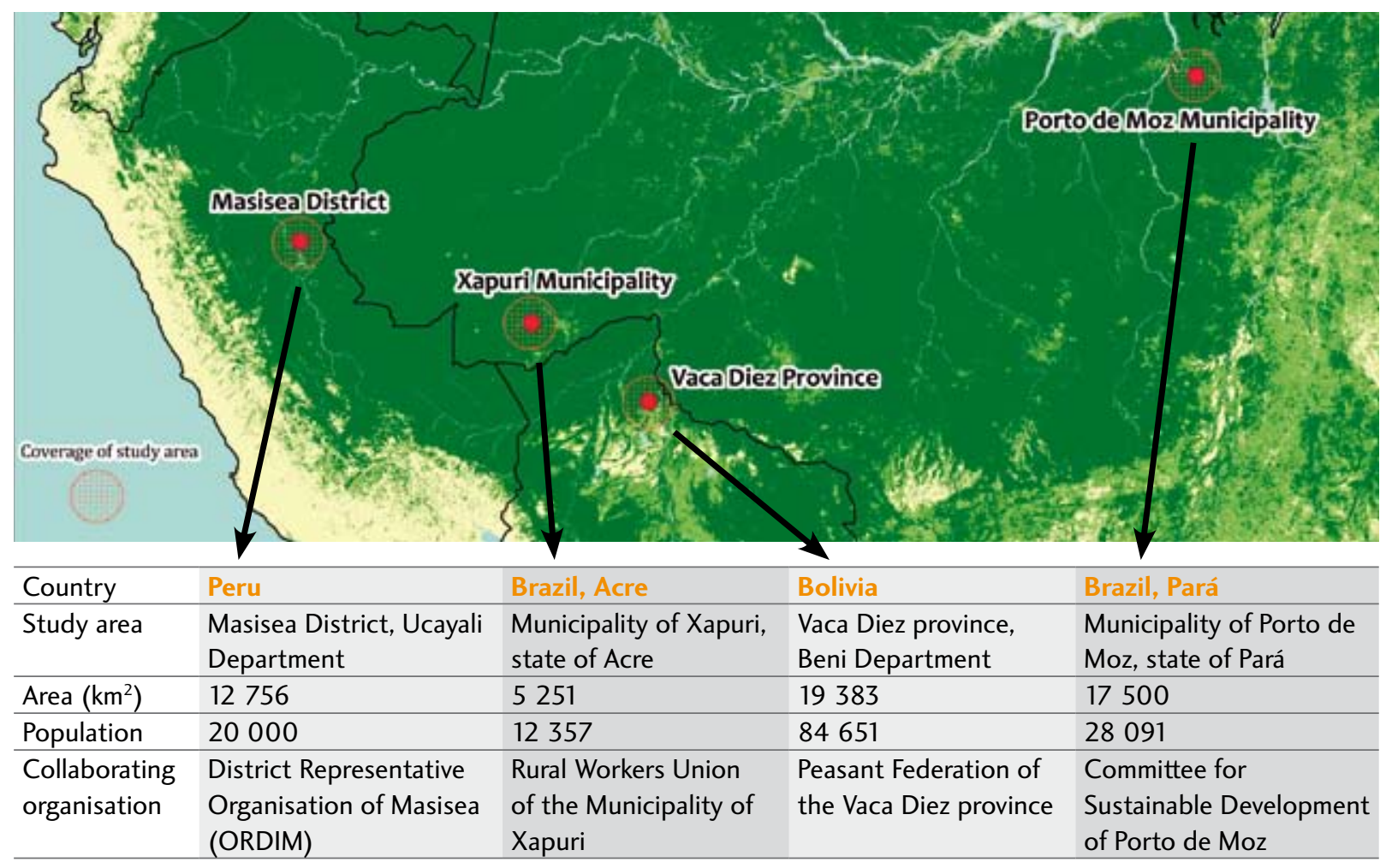


Figure 2. Communities working with development agencies and loggers

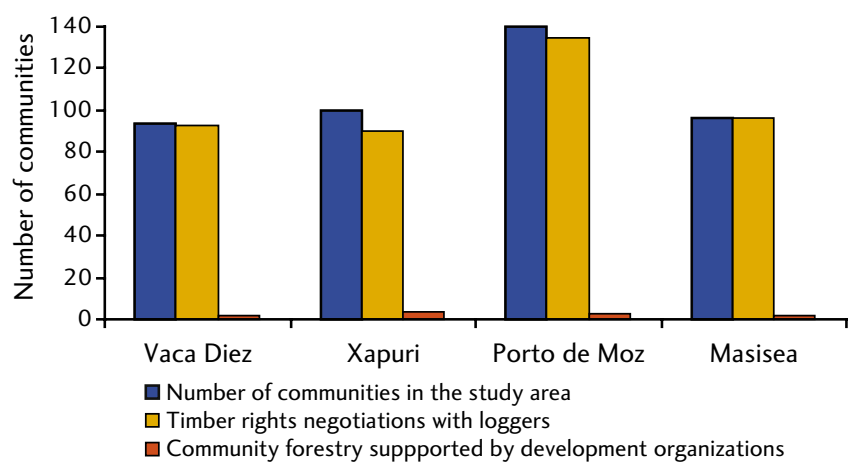

High implementation costs are one reason why community forestry schemes have not been widely adopted - initiatives in each study area ranged in cost from US\$25 000 to US\$377 000 per community, depending on their scope and intensity. Without this kind of support, none of the communities showed any interest in community forestry schemes.

Another reason is the relatively low financial return (Medina \& Pokorny, 2008). Families received a relatively high income per cubic meter of timber (Table 1), but they also invested a relatively high amount of time in field activities such as timber inventories and processing, and numerous training workshops. As a consequence, the average income per person per work day was only US $\$ 8.69$, even with development agencies subsidising the scheme.

By comparison, families informally negotiating with loggers were poorly paid for the harvested timber, but still received an average net income of
US\$28.14 per person per working day because they invested much less time in activities related to the logging. This is extremely attractive when local job opportunities are very few and badly paid (Table 1).

The benefits derived from logging and community forestry schemes were also not evenly spread. In the case of community forestry projects, only about 30 per cent of families in each relevant community were involved and benefited from the commercialized timber as well as sporadic jobs and improved access through roads being built to their farms. However, families negotiating with loggers also mentioned and valued these kinds of indirect benefits.

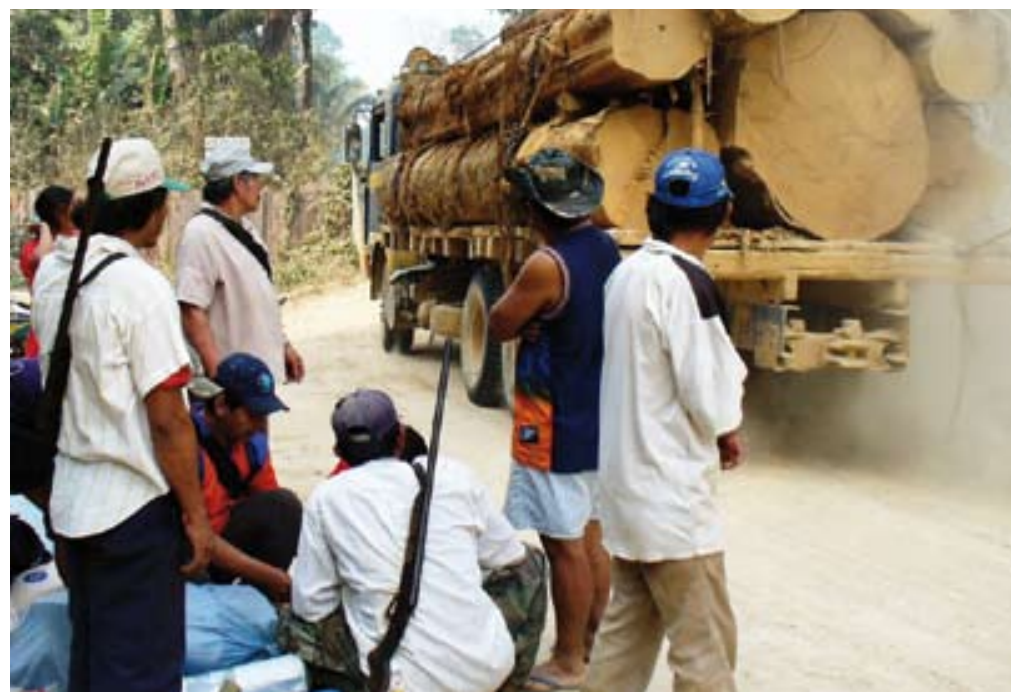

Community members watch logs being removed from their forest Loggers usually buy community timber rights and exploit the forest without community control. (Vaca Diez, Bolivia)

Table 1. Net income derived by communities from timber rights negotiations with logging companies and community forestry management initiatives supported by development agencies

\begin{tabular}{|c|c|c|c|c|c|c|c|c|c|c|}
\hline \multirow[b]{2}{*}{ Case studies } & \multicolumn{5}{|c|}{ Community forest management } & \multicolumn{5}{|c|}{ Negotiation with loggers } \\
\hline & $\begin{array}{l}\text { Vaca } \\
\text { Diez }\end{array}$ & Xapuri & $\begin{array}{l}\text { Porto } \\
\text { de Moz }\end{array}$ & Masisea & Average & $\begin{array}{l}\text { Vaca } \\
\text { Diez }\end{array}$ & Xapuri & $\begin{array}{c}\text { Porto de } \\
\text { Moz }\end{array}$ & Masisea & Average \\
\hline $\begin{array}{l}\text { Total cash income } \\
\text { received (US\$) }\end{array}$ & 2750 & 7416 & 8977 & 120 & 4815 & 1392 & $\begin{array}{r}14 \\
280\end{array}$ & 9520 & 720 & 6478 \\
\hline Volume sold $\left(\mathrm{m}^{3}\right)$ & 550 & 618 & 450 & 9 & 406 & 693 & 6300 & 42000 & 3300 & 13073 \\
\hline Income per $\mathrm{m}^{3}$ (US\$) & 5.00 & 12.00 & 19.95 & 13.33 & 12.57 & 2.01 & 2.27 & 0.23 & 0.22 & 1.18 \\
\hline $\begin{array}{l}\text { Number of persons } \\
\text { participating }\end{array}$ & 36 & 10 & 10 & 5 & 15 & 20 & 15 & 20 & 76 & 33 \\
\hline $\begin{array}{l}\text { Working days per } \\
\text { person per year }\end{array}$ & 35 & 30 & 135 & 20 & 55,00 & 4 & 25 & 10 & 1 & 10,00 \\
\hline $\begin{array}{l}\text { Income per working } \\
\text { day per person (US\$) }\end{array}$ & 2.18 & 24.72 & 6.65 & 1.2 & 8.69 & 17.40 & 38.08 & 47.60 & 9.47 & 28.14 \\
\hline $\begin{array}{l}\text { Local wages per day } \\
\text { (US\$) }\end{array}$ & 2 & 5 & 5.2 & 1.5 & 3.43 & 2 & 5 & 5.2 & 1.5 & 3.43 \\
\hline
\end{tabular}




\section{The effect of outside influence on local organization}

Timber companies are notorious for using their power to make local communities do what the companies want (Medina, 2004). Field research, however, indicates that the relationships between communities and development agencies are also unequal, with communities forced to adopt externally defined forest management schemes. Development agencies impose their schemes by three different means:

First, development agencies prescribe the entire production chain, including what product to exploit, management practices in the field, which market to reach, the organizational structure and the marketing strategy. Community members were trained in specific field activities such as inventories and tree felling, but the agency retained control over the concept and related activities. When adopting externally-conceived schemes, communities have limited opportunities to develop their own ideas on forest management.

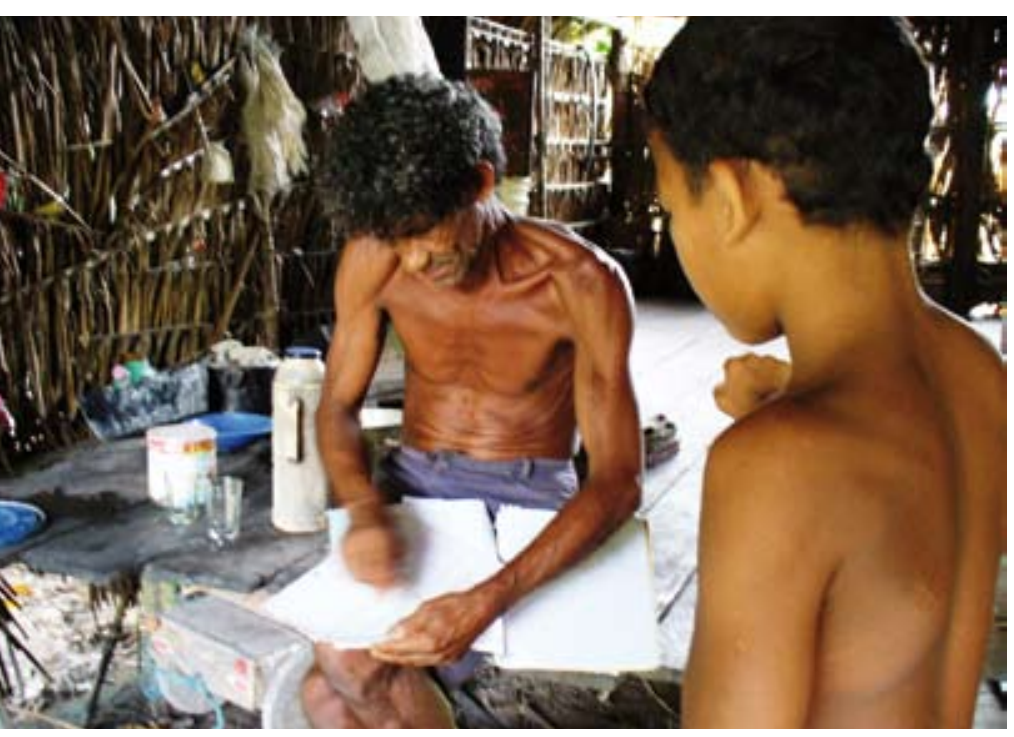

A community member writes a list of goods received from a logger in exchange for his timber. Paternalistic relationships with outsiders can hinder communities in developing their own forest management approaches. (Porto de Moz, Brazil)
Second, the agency relationships established with communities are characteristically paternalistic. In both cases, the families are grateful to loggers and development agencies, and most assume the ideas of these players as their own. The paternalistic relationship hinders local organization by causing conflicts with the rest of the community who missed out, and by creating a disconnect between communities as a whole and their local representative organizations.

Third, to further strengthen their concept of forestry, development agencies as well as loggers systematically use the discourse on sustainable forest management. Loggers claim that they, unlike the local communities, have the necessary technical capacity to ensure professional and sustainable forest management. On the other hand, development agencies claim that market influences and negotiations with loggers entice communities to over-exploit their resources for limited financial benefits. Thus, they argue that communities have to be trained to manage their forests adequately on their own. The idea that external experts know best dominates the community forest debate, effectively silencing the voices of the communities themselves.

\section{The Potential for Locally-Driven Development}

In view of the limited benefits from logging companies and community forestry initiatives, alternatives are required. To this end, the study explored the potential for local communities to develop their own initiatives to effectively use their forests in accordance with their own interests and capacities.

In contrast to current debates focused on a perceived lack of local managerial capacity, communities in all four study areas were found to have initiated processes to regulate access to and use of valuable local resources. Examples included demarcating community forest areas and establishing norms to regulate access to areas with Brazil nut and rubber trees, as well as fishing agreements (Table 2).

Table 2. The Regulatory Systems, Community Organizations and their Achievements

\begin{tabular}{lllll}
\hline & Vaca Diez & Xapuri & Porto de Moz & Masisea \\
\hline Resource & Brazil-nut trees & $\begin{array}{l}\text { Rubber and Brazil-nut } \\
\text { trees }\end{array}$ & Fish and timber & Timber \\
\hline $\begin{array}{l}\text { Systems defining } \\
\text { access and use }\end{array}$ & $\begin{array}{l}\text { Communal areas for } \\
\text { Brazil-nut collection }\end{array}$ & $\begin{array}{l}\text { Communal areas for } \\
\text { tapping rubber trees }\end{array}$ & $\begin{array}{l}\text { Fishing agreements } \\
\text { and community forests }\end{array}$ & $\begin{array}{l}\text { Territories and } \\
\text { regulations over } \\
\text { timber extraction }\end{array}$ \\
\hline
\end{tabular}




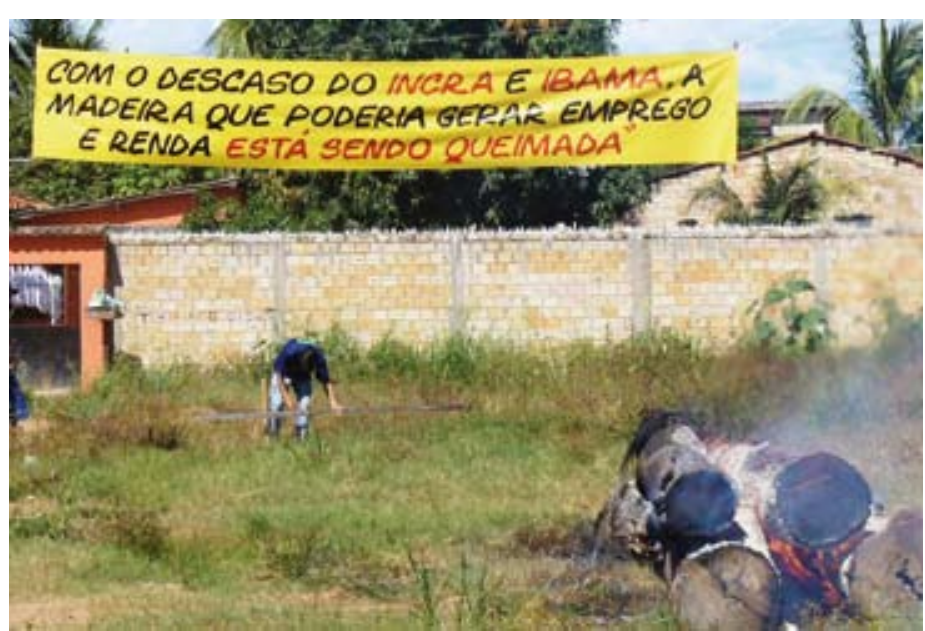

Loggers advertise income and jobs for the local population. Loggers and development agencies both justify their perspectives on how Amazon communities should use their forests (Altamira, Brazil).

To better understand the possibilities for developing local management schemes, the circumstances were analyzed under which communities: (1) developed management schemes according to their interests and capacities; (2) were able to identify common interests and organize themselves to enforce their approaches; and, (3) managed to have their approaches acknowledged by the society at large.

The analysis revealed that local management schemes always emerged when external players such as large-scale farmers, loggers and commercial fishermen arrived and threatened community access to resources. In no cases had these systems existed before. The local management schemes implied setting up norms to regulate the access to and use of resources by external players and also by local families.

In all successful examples, communities organized themselves to enforce their rights against outsiders with whom they had detached (in contrast to paternalistic) and even conflicting relationships. Such situations occurred when the private sector moved in to exploit community resources without negotiation; particularly in these circumstances, communities managed to identify shared interests and organize to resist the common threat.

In all studied regions, demands by local communities and their representative organizations received little attention in the external political arena. Community management systems were only acknowledged through alliances with powerful partners, such as environmental organizations.
However, in return for their support, these partners generally required communities to adapt their initial demands to accommodate the interests, concepts and arguments of their new allies.

\section{Conclusions}

Contrary to expectations, indigenous and traditional communities have not benefited significantly from their timber resources being managed in formally authorized and strongly promoted pilot community forest initiatives. The current approach has intrinsic limitations such as high implementation costs, low take-up, limited financial viability, and unsustainable practices once external support dries up. Generally, communities continue to informally negotiate timber rights with loggers.

The limited nature of the benefits is mostly due to communities exploiting their forests based on relationships of dependency with external players, whether they be well-meaning development agencies or logging companies. This dependency in turn stifles locally-conceived initiatives.

Instead, development agencies and logging companies enforce management schemes defined in accordance with their own interests and expertise, without adequately considering local interests, priorities and capacities. The paternalistic character of the relationship and the hegemonic discourse on sustainable forestry that they promote restricts a more successful collaboration. Communities simply become even more dependent upon external players, and lose their ability to develop self-governed natural resource management schemes.

Self-governed approaches emerge from local knowledge in response to ever-changing contexts, and depend less on technological content than on social control and objectives. For communities on the Amazon frontier, developing their own approaches depends principally on the potential to establish autonomous (in contrast to dependent) relationships with external players.

Once local communities regulate the access to and use of resources, they will tend to implement and enforce these regulations. Local systems also tend to be more flexible and readily adaptable in dynamic contexts, as are typical in the Amazon 
region (Muñoz et al., 2007). Non-dependent communities are then able to direct their own development, strengthening local people's roles in society, and strengthening society as a whole.

This study revealed that communities themselves become autonomous, rather than being made so by external efforts. This does not deny the importance of external assistance but collaboration requires an equitable balance of power between local communities and external players, who otherwise naturally tend to dominate due to superior resources, qualifications and public influence. With more balanced relationships, communities can participate as autonomous protagonists for and beneficiaries of pro-poor development policies in the region.

\section{Policy Recommendations}

A new approach for supporting Amazonian communities managing their forest must be developed. This new approach must recognize that functional community forest management schemes require the following:

- Instead of intensive external support in pilot initiatives, a framework of non-intensive or extensive support should be developed, reaching a greater number of communities

- Instead of prescriptive support, communities should be allowed to have the autonomy to develop local concepts of forest use

- Instead of focusing on command and control, local regulatory systems should be allowed to emerge, defined by communities and their representative organizations

\section{References}

Medina, G. 2004. Ocupação cabocla e extrativismo madeireiro no Alto Capim: Estratégias de

Reprodução camponesa. Acta Amazônica, 34 (2): 315-324.

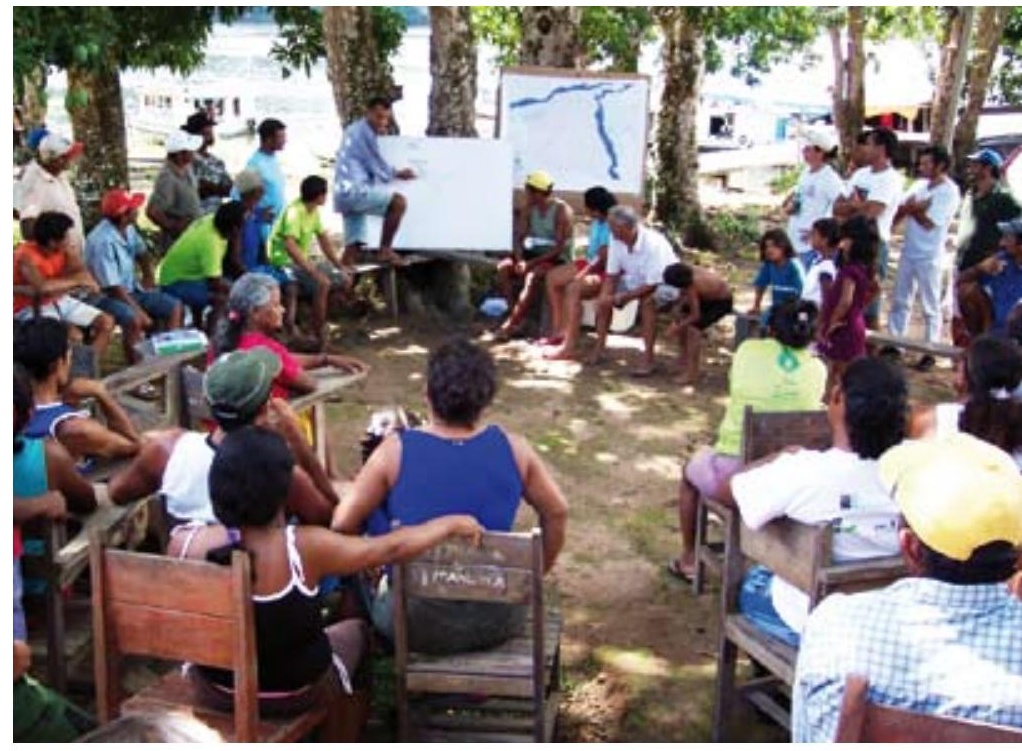

Neighbouring communities discuss the rules of a fish agreement. Across the Amazon, communities are developing efficient approaches to regulate access and use of resources. (Porto de Moz, Brazil)

Medina, G. \& Pokorny, B. 2008. Avaliação financeira do manejo florestal comunitário. Brasília, IBAMAProManejo, 224p.

Muñoz, I., Paredes, M. \& Thorp, R. 2007. Group inequalities and the nature and power of

collective action: case studies from Peru. World Development, 35, (11), 1929-1946.

Pokorny B. and J. Johnson 2008. Community forestry in the Amazon: The unsolved challenge of forests and the poor. ODI Natural Resource Perspectives 112, 4p.

Sabogal, C., Snook, L., Boscolo, M., Pokorny, B., Quevedo, L., Lentini, M., Colán, V. 2008 Adoção de práticas de manejo florestal sustentável na Amazônia: impulsores e limitantes. Belém: Cifor, $8 \mathrm{p}$.

Shanley, P., Luz, L. \& Swingland, I. 2002. The faint promise of a distant market: A survey of

Belém's trade in non-timber forest. Biodiversity and Conservation, 11, 615-636. 